\title{
Landscape Character: Relationship between Existing Acts, Policies and Guidelines in Malaysia
}

\author{
Mohd Zulhaili Teh, Izham Ghani, Marina Abdullah, Noorsazwan Ahmad Pugi
}

Faculty of Architecture, Planning \& Surveying,

Universiti Teknologi MARA, 32610 Seri Iskandar, Perak

mohdz841@uitm.edu.my, izham025@uitm.edu.my, marina84@uitm.edumy, noors240@uitm.edu.my Tel:: 013-2987616

\begin{abstract}
Landscape character is an essential national resource which includes outstanding natural and cultural heritage. Landscape character assessment can make a valuable contribution to the formation of planning policies, to the allocation of land for development and to control any development activities. Efforts in landscape character for development, preservation and conservation existed in Malaysia indirectly through the various acts, policies and guidelines. Legislation on landscape character is to provide landscape character assessment at national, regional and local levels through systematic ways in contributing to the protection, planning and landscape management.
\end{abstract}

Keywords: Landscape character; acts, policies and guidelines; landscape character assessment

eISSN: 2398-42870 2020. The Authors. Published for AMER ABRA cE-Bsby e-International Publishing House, Ltd., UK. This is an open access article under the CC BYNC-ND license (http://creativecommons.org/licenses/by-nc-nd/4.0/). Peer-review under responsibility of AMER (Association of Malaysian Environment-Behaviour Researchers), ABRA (Association of Behavioural Researchers on Asians) and cE-Bs (Centre for Environment-Behaviour Studies), Faculty of Architecture, Planning \& Surveying, UniversitiTeknologi MARA, Malaysia.

DOI: https://doi.org/10.21834/ebpj.v5i14.2259

\subsection{Introduction}

Landscape is a term used by many different disciplines with varies connotations. Landscape is defined as a view of scenery prospect that can be taken in, at a glance from a point. It is about what we see and sense when we see it and the system which supports both of this. Viewing the landscape as a spatial social-ecological system allows identification of specific management challenges: integration of multiple views, multiple levels of the organisation, intricate spatial-temporal patterns and uncertainties (Allain et al., 2017).

It is widely appreciated through its aesthetic beauty and significant contribution to regional identity and sense of place. Landscape Character Assessment (LCA), is the process of describing the recognisable pattern of elements that occurs in a particular landscape. Variations in geology and soils, landform, land cover and vegetation, boundaries and settlement pattern give different landscapes its own distinctive character and unique sense of place. It is mainly the combinations of physical landscape component and anthropogenic element and its component that creates the landscape character, which makes different landscape distinct from each other (Swanwick, 2004).

LCA provides useful assistance in strategy formulation; strategies plan for particular development areas, both at the strategic and policy-related levels and on individual development projects. The focus of the application is on defining specific areas of the landscape, including regional identification, mapping of the justification for special treatment and input on management plans, and other management initiatives. More recently, there has been an increasing emphasis on formulating strategies and guidelines to help preserve and enhance the diversity of characters on the broader landscape. Most of the related policies and guidelines in landscape character are touched on administrative affairs, managing, developing and protecting the land based on the quantity and quality of the physical landscape but no specific clause mentioned.

eISSN: 2398-4287@ 2020. The Authors. Published for AMER ABRA cE-Bsby e-International Publishing House, Ltd., UK. This is an open access article under the CC BYNC-ND license (http://creativecommons.org/licenses/by-nc-nd/4.0/). Peer-review under responsibility of AMER (Association of Malaysian Environment-Behaviour Researchers), ABRA (Association of Behavioural Researchers on Asians) and cE-Bs (Centre for Environment-Behaviour Studies), Faculty of Architecture, Planning \& Surveying, UniversitiTeknologi MARA, Malaysia.

DOI: https://doi.org/10.21834/ebpj.v5i14.2259 
Therefore, the objectives of this study are to identify the existing acts, policies, and guidelines related to landscape character. This study also to analysed some of the acts, policies, and guidelines and provided examples on areas that will contribute to the application of landscape character area and the visual landscape of the surrounding area to see changes in the landscape of the area explored. This study aims to provide a direction structure for the legislation approach to support landscape character application. It will contribute to the decision making in development, preservation, and conservation, and management of the landscape resources in Malaysia.

\subsection{Literature Review}

\subsection{Landscape and Landscape Character}

Landscape is a vital part of our environment which influences the quality of life. In a broader sense, it commonly refers to the appearance of a land cover but also includes elements such as its shapes, textures and colours. It encompasses the whole natural and man-made environment. Landscape is defined as the character and appearance of land, including its shape, form, ecology, natural features, colours and elements, and the way these components combine" (Matloob, 2014; DETR \& CABE, 2000). The patterns and textures of buildings, streets, open spaces and trees, and their interrelationships within the built environment are each essential parts of our more extensive landscape heritage. The landscape importance is based on two aspects, focused on the design and protection of scenic quality and emphasised dynamic multifunctional links between the ecosystem service and human well-being. Landscape is the result of the interaction between humans and nature, which often conveys a different character to the land. (Atik et al., 2015). Planning and monitoring of landscapes cannot be reduced to its outstanding features but must take into account all its characteristics. (Martin et al., 2016).

Thus, it can be described in a variety of components system of our environment, including natural and cultural, that interact together dynamically. European Landscape Convention (ELC) defines landscape as "an area perceived by people, whose character is the result of the action and interaction of natural and human factors" (Council of Europe Treaty Series no. 176, 2000). Identification of essential features process in the landscape depends on the perspective of the landscape itself. For example, an urban community sees farm differ from a farmer, and an urban farmer perceived environment that urban might differ from the urban community's perspectives. Therefore, it is evidence that landscape is a relationship between people, places and part of the setting for our lives. Landscape has been shaped by variations of landform and land cover that can be recognised as a character that represents a sense of place.

Landscape is the natural and cultural features of the environment. Characters are distinct, recognisable patterns in the landscape that were comprised as a result of human and nature interactions. (Atik et al., 2016). Landscape character means a distinct, recognisable and consistent pattern of elements, be it natural (soil, landform) or human (human settlement and development) in the landscape that makes it different from others, rather than better or worse (Swanwick, 2002). Landscape character also can be defined as the pattern that arises from particular combinations of the different components that can provide a sense of place to our surroundings (The Countryside Agency, 2002). Landscape characters demonstrate precise features and values that exist in the current environment and provide information for those who use, manage, live in, benefit from and enjoy the landscape. (Atik et al., 2016). Landscape character was assessed based on quality, strength and distinctive elements that exist, which will be coordinated with landscape development strategy. Landscape character values regarding coherence, complexity, naturalness, visual scale, disturbance, historicity, and ephemera are obtained using Geographic Information Systems. (Martin et.al , 2016).

Thus, Landscape Character Assessment (LCA) has gained a significant recognition around the globe, the understanding of the challenges faced by planners and decision-makers in incorporating LCA processes and outputs in land-use planning remains insufficient (Trop, 2017). LCA is a method commonly used by landscape architects, planners and researchers to describe the different characteristics of landscapes. (Zakariya et al., 2019). It helps to understand, articulate and identify features that give a locality' sense of place' that make it different from neighbouring areas (The Countryside Agency, 2002). LCA can be used in many situations, for example, in devising indicators to gauge landscape change and to inform regional planning, local development, environmental assessment and the management of protected landscapes. LCA emerged as an appropriate way to look at the landscape because it provides an objective and structured approach to identifying character and distinctiveness as well as its value (The Countryside Agency, 2002). LCA allow us to compare properties of different regions in terms of scenic or tranquility at a macro-level by identifying the character. At a micro-level, we can zoom into individual descriptions and landscape elements to understand how particular places are experienced in context. Essential challenges for LCA include integrating perspectives and perceptions from multiple people (Swanwick \& Fairclough, 2018). Therefore, elaborating LCA studies into landscape plans and calling for its integration within spatial planning has potential (Atik et al., 2015) in Malaysia.

\subsection{Relationship Between Legislation}

The changes of land use intensification and its effects on landscape pattern as well as landscape types and their dynamic of change in order to describe the implications for land use planning and management (Arif \& Nakagoshi, 2006). Any form of development can harm the landscape through the intrusion of man-made structures and patterns into natural-dominated areas. It has the effect of reducing the beauty of the scenery and features of something appreciated by humans. In Malaysia, rapid changes in land use invariably portrayed have a relationship with environmental degradation (Arif \& Nakagoshi, 2006).

Furthermore, a variety of land uses, and other activities can threaten the landscape character, including (i) Distribution of areas and development in the urban area. (ii) Single buildings/structures or clusters building; (iii) Infrastructure systems, including roadways, highways, pylon and transmission towers; (iv) Removal and degradation of vegetation and loss of identity associated with the land cover; (v) Any activities (deforestation/mass agricultural), covering terrestrial and coastal forms, producing sediment loads during harvesting; 
(vi) Agriculture that includes irrigation and livestock systems; and (vii) Groundwork that alters the shape of the terrain and the structure of the soil. Developmental activities might have been less intense in the human landscape, but they had a much more significant impact on the natural ecosystem (Arif \& Nakagoshi, 2006).

Generally, the main issues are the cumulative effect of a particular observation on the landscape character that in some circumstances, the landscape may absorb a small amount of development but continuous development and lack of control can have serious adverse effects. Across Malaysia, the problem with the loss of native forest cover, wetlands, and other endemic features has led to the widespread erosion of this landscape character.

\subsection{Methodology}

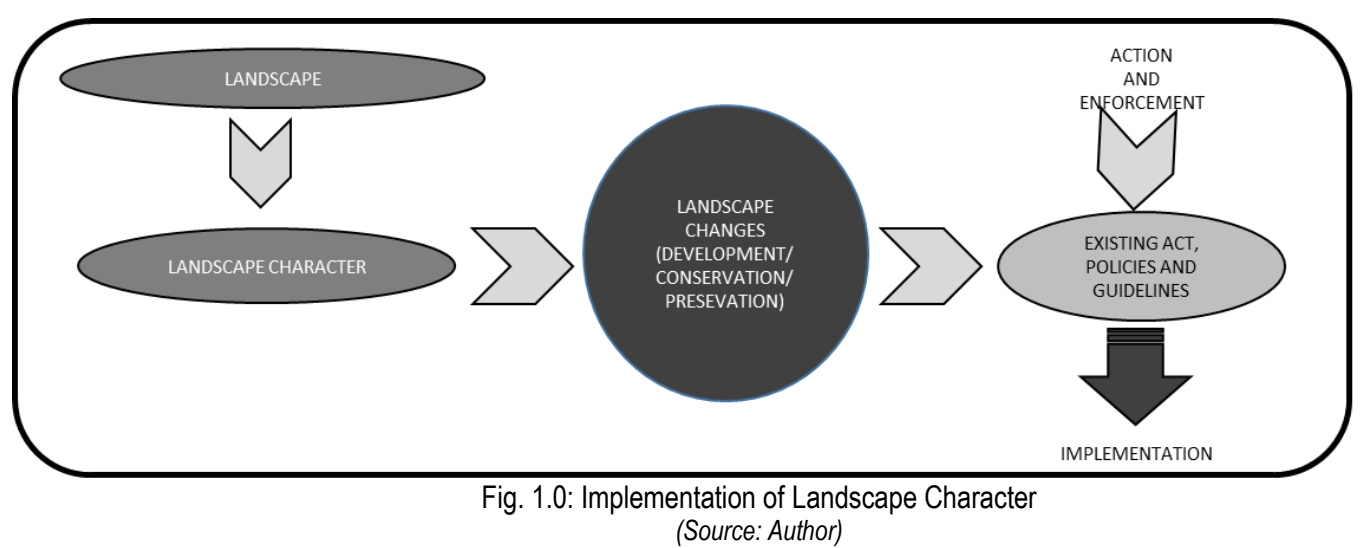

The methodology of this study is formed to identify the landscapes and landscape character in a broader context in Malaysia (Fig. 1.0) as the landscape itself has diverse definitions. In this context, the landscape character is seen as a physical element of the land cover. It is clear to be defined and monitored. Therefore, any changes that occur on land occur frequently and are known as landscape change. Changes in land cover also influenced the landscape types and their dynamic of change (Arif \& Nakagoshi, 2006).

Landscapes often change according to specific needs, whether they are to be developed, preserved or conserved. The landscape changes are particularly evident and significant in small and rapidly developing countries, with a high diversity of natural and cultural landscapes (Trop, 2017). Any changes must be following the rules and regulations for this landscape change to be controlled. This is because development, preservation and conservation are either it can control or not. Through legal approach in this landscape character application, the control over each landscape change can be monitored. If there is a violation of applicable laws and regulations, enforcement action may be taken.

There are no specific laws regarding landscape character. Therefore, this study seeks to find any relevant laws, policies and guidelines that relate to landscape character. Existing laws are intended to be applied to suppress any lack of control of landscape changes through action and enforcement. When it is adaptable and adheres to existing requirements, new landscape changes are implemented to make it significant. The limitation of this study is that there are too many landscape-related laws at various stages of implementation in Malaysia generally and in states or regions in particular. Therefore, only laws and regulations relating to the landscape character are significant and enforceable.

\subsection{Findings}

In Malaysia, legislative agencies are made up of various levels and bodies to enforcement in the implementation of landscape-related acts, policies and guidelines. Three levels play an essential role in the implementation of development, preservation and conservation. Firstly, the highest laws are implemented at the national level, which applies to all states and should be the guiding principle in each process. The second level is at the state level, where the fundamentals of national rankings are detailed and adapted to the state. The third level is where two basic laws apply at the national and state level and are detailed in more comprehensive at the district level. At this stage, enforcement action is being carried out by the local authorities and making their actions and enforcement more effective.

In a nutshell, there are no acts, policies and guidelines that directly mentioned the elements of landscape character but contained in the existing policies that allow them to be considered and enforced together. This relationship is to ensure that at least the landscape character in Malaysia is protected and to the point of being legally informed. Table 1.0 describes the relationship of landscape character to legislation, programs, policies and guidelines implementation in Malaysia. It explains the relevance of the legislature, its important strategy that can be implemented and correlated with the aspects and areas of landscape and landscape character. From the above method, landscape character and landscape change can be translated by dividing the resources distributed in the table. The detailed discussion is described in section 5.0 . 
Table 2.0: Landscape concerning Legislation, Programs, Policies and Guidelines Implementation for Landscape Character in Malaysia.

\begin{tabular}{llll}
\hline No & Programme / Acts, Policies, Guidelines & Strategy & $\begin{array}{l}\text { Correlated with the aspects and areas of } \\
\text { landscape }\end{array}$ \\
\hline 1 & Landscape resources
\end{tabular}

National Landscape Policy $2011 \quad$ Strengthen and enhance landscape quality for achieving the most beautiful Country Parks

\begin{tabular}{ll}
\hline $\mathbf{2}$ & Land Resources \\
& National Land Code 1965 \\
Town and Country Planning Act 1976, \\
1993
\end{tabular}

Land Conservation Act 1960

Street, Drainage, Building Act 1974

State Plan under the State Planning

Committee to manage natural

resources and man-made products

uThe National Physical Plan (NPP) State

Structure Plan (SSP) and the District Local

Plan (DLP), Special Area Plan (SAP)

\begin{tabular}{cc}
\hline 3 & Water Resources \\
\hline Water Act 1920,
\end{tabular}

1920 ,

Amendment 1989

Environmental Quality Act 1974

Water Usage Guidelines

$4 \quad$ Forest Resources

National Forestry Act 1984
Comprehensive legislation relating to land

the gazetting of land, transfer of land, land registration, land transactions and others in Peninsular Malaysia

Increase standards in land use planning Reducing the negative impacts of land use such as erosion and landslides

To plan the physical development and socio-economic

Advisory and Governance Development

Stage of the Federal Government,

State and Local Authorities

Development plan of states, districts and particular areas

To control the development of high land,
protect watersheds

Developing a Landscape Plan and Urban Area which has a distinctive landscape character, harmonious and sustainable natural resources and to remain in the current socio-cultural development and modernisation.

Landscape Development of the urban landscape, countryside and specific areas

Areas beautification

Preservation of landscape

Landscape management

Landscape maintenance

Planning and design of particular landscape areas, sensitive and important.

Important component of the landscape and the preservation of water bodies

Monitor and supervise matters related to Landscape maintenance of water catchment areas and water quality waterfront

Increase capacity and effectiveness of Natural landscape and forests

reforestation

National forest inventory

Increase R \& D in forestry

Protect and manage forests for

biodiversity, habitat and water resources

Managing the community forest and forest product efforts

\begin{tabular}{lll}
\hline $\mathbf{5}$ & Biodiversity / Wildlife Resources & \\
\hline National Biodiversity Policy (April 1998) & $\begin{array}{l}\text { Enforcement of laws for the protection of } \\
\text { biological diversity }\end{array}$ \\
\hline $\begin{array}{l}\text { Wildlife Protection } \\
\text { Act 1972.1976 }\end{array}$ & $\begin{array}{l}\text { Protection to habitats and wildlife, nature } \\
\text { education, research, recreation and eco- } \\
\text { tourism, service of ecological processes } \\
\text { and integrity habitat }\end{array}$ \\
\hline National Parks Enactment (Terengganu) & $\begin{array}{l}\text { Formation of wildife and vegetation } \\
\text { management of the state }\end{array}$ \\
\hline Endau Rompin National Park (Johor) 1993 & $\begin{array}{l}\text { Creating protected areas where the state } \\
\text { and threatened species conservation, } \\
\text { outdoor recreation centre and research. }\end{array}$ \\
\hline
\end{tabular}

Information on forest landscape

Knowledge and the advancement of knowledge about the forest landscape

Management of natural habitats and landscape

Design and management of community forests and culture

Management of natural habitats and landscape

Landscape of outdoor

recreation areas

Development of landscape design in the natural area for eco-tourism in harmony with high biodiversity areas integrity habitat

\begin{tabular}{|c|c|c|c|}
\hline & Biosafety Act 2007 & $\begin{array}{l}\text { Complement the Government's intention to } \\
\text { conserve the country and making } \\
\text { biotechnology as a source of new wealth }\end{array}$ & \\
\hline \multirow[t]{3}{*}{6} & Heritage resources & & \\
\hline & National Heritage Act 2005 & \multirow{2}{*}{$\begin{array}{l}\text { Conservation and preservation of national } \\
\text { heritage, natural heritage, both tangible, } \\
\text { intangible heritage and geological heritage }\end{array}$} & \multirow[t]{2}{*}{$\begin{array}{l}\text { Planning and design of a cultural landscape heritage } \\
\text { area and area of geological heritage }\end{array}$} \\
\hline & $\begin{array}{l}\text { Formation of Langkawi and Kinta Geo- } \\
\text { parks }\end{array}$ & & \\
\hline \multirow[t]{2}{*}{7} & Geological resources & & \\
\hline & $\begin{array}{l}\text { National Mineral Policy } 1 \text { (1992) } \\
\text { National Mineral Policy } 2 \text { (2008) } \\
\text { Selangor Mineral Enactment, 2000 } \\
\text { Minerals Development Act } 1994 \\
\end{array}$ & $\begin{array}{l}\text { Enhance the mineral sector's contribution } \\
\text { to socio-economic development through } \\
\text { the efficient development of natural } \\
\text { resources }\end{array}$ & $\begin{array}{l}\text { Develop and diversify the mineral sector through the } \\
\text { discovery and utilisation of mineral resources the } \\
\text { country with emphasis on environmental protection and } \\
\text { sustainable development. }\end{array}$ \\
\hline
\end{tabular}

\subsection{Discussion}

From Table 1.0, it can be concluded that there are seven indirect resources classifications of policy and landscape-related guidelines in Malaysia. This classification is to facilitate the isolation of the scope of enforcement and to limit its enforcement in a resource-based landscape. It consists of Landscape resources, Land Resources, Water Resources, Forest Resources, Biodiversity / Wildlife Resources, 
Heritage Resources and Geological Resources. All of these resources are crucial to analyse the landscape elements according to their respective definitions from the perspective of various professions and fields.

We chose two (2) example of resources in Table 2.0. Firstly, Land Resources encompasses two (2) significant Acts for the physical development landscape in Malaysia, which is the National Land Code 1965 and Town and Country Planning Act 1976 Amendment 1993. The connection between landscape character and the National Land Code 1965 is through the idea of comprehensive legislation relating to land, the gazetting of land, transfer of land, land registration, land transactions and others in Peninsular Malaysia. This does not include Sabah and Sarawak as the Sarawak Land Code 1958, and the Sabah Land Ordinance 1930 are enacted earlier in the colonial era. It makes a significant difference as it protects the indigenous lands of the indigenous peoples of both countries.

Thus, the Town and Country Planning Act 1976 Amendment 1993 also provide increased standards in land use planning to control any development on the ground. For example, in the Town and Country Planning Act there is a reference to Subsection 2 (1) of the Town and Country Planning Act 1976 (Act 172) defining vacant land as: "any land which is either enclosed or unorganised or reserved for layout. in whole or in part as a public flower park, public park, public recreation and recreation park, public wind eater, public walkway or as a public place. "This rule applies in every development plan through the reporting by the local authority, which requires that each development plan have at least $10 \%$ of open space in the entire development area.

Secondly, is the most prominent landscape policy in Malaysia is the National Landscape Policy (NLP) introduced in 2011. The purpose of the NLP is to provide a beautiful nation, comfortable, and safe living environment at the same time to improve the overall quality of life in Malaysia. The NLP also facilitates and directs the country towards balanced with sustainable development as well as ensuring national landscape resources and assets are managed well. Thus, the NLP is also to protect landscape resources as the Nation's heritage with high value for the present and future generations. This policy takes into account various aspects that are in place to ensure their implementation and enforcement are in line with the current legal situation in Malaysia. It covers Malaysia Five Year Plan (MFYP), National Agriculture Policy, National Forestry Policy, National Urbanization Policy, Environmental Policy, National Biodiversity Policy and Green Technology Policy. From the two examples of these findings, the landscape character in Malaysia is rhetorically oriented only in principle. However, the conditions for any implementation are not intended to be followed and enforced. These existing policies only fit their respective interests, not intended on the landscape character that intends to use them.

Currently, in Malaysia, the National Landscape Department under the Ministry of Housing and Local Government has taken the initiative to introduce the Manual of Landscape Character Assessment in 2012. This manual is introduced and formulated in accordance with the statement of National Landscape Policy 2011, which is transforming Malaysia into a Beautiful Garden Nation by 2020. This manual was developed to help in the preparation of better landscape development plans in Malaysia and also emphasised its importance LCA to assist the development and sustainability (Zakariya et al.,2019). However, its implementation is still in its early stages.

Furthermore, the department also is working to create a specific landscape act. The draft of the Act has been enacted several times and needs to be refined in order to be tabled in Parliament. This Act is significant in making landscapes generally and landscape, in particular, accessible and helps to balance for landscape development and natural landscapes. From this study, it is hoped that it will assist in drafting the legislative draft as well as strengthening the existing rules and regulations. It will have long-term implications for the development, preservation and preservation of the landscape in Malaysia.

\subsection{Conclusion \& Recommendations}

The process of formulating the landscape character can be considered as a significant effort to be performed in Malaysia. One of the methods to achieve this is through persistence in preserving and enhancing the unique characteristics of the landscape environment that includes the socio-cultural and natural resources in Malaysia (Zakariya et al., 2019). This shows that the importance of this study in creating a tool for landscape planning is eminence. Understanding the importance of the landscape must be understood holistically and systematically, so that landscape resources that form characters of local landscapes can be conserved, preserved and protected. Therefore, policies, acts and guidelines that emphasis strictly on the landscape character should be formulated and applied in tandem with the existing planning practices so that the best strategy for distinctive and significant landscape can be implemented.

This study hopes to assist stakeholders in providing specific legislative guidance on landscape character that can be used immediately as the above initiatives would take a long time to implement. Therefore, immediate action with available resources should be used well.

\section{Acknowledgements}

The authors would like to acknowledge Universiti Teknologi MARA Perak Branch for providing necessary assistance for the preparation of this research.

\section{References}

Abdullah, S. A. \& Nakagoshi, N. (2016). Changes in landscape spatial pattern in the highly developing state of Selangor, peninsular Malaysia. Landscape and Urban Planning. Volume 77, Issue 3, Pages 263-275.

Allain, S., Plumecocq, G., Leenhardt, D. (2017). How Do Multi-Criteria Assessments Address Landscape-level Problems? A Review of Studies and Practices. Ecological Economics, Volume 136, Pages 282-295. 
Atik, M., Canay, R., Ortaçeşme, V. (2016) Clusters of landscape characters as a way of communication in characterisation: A study from side, Turkey. Journal of Environmental Management. Volume 182, Pages 385-396

Atik, M., Canay, R., Ortaçeşme, V., Yildirim, E. (2015). Definition of landscape character areas and types in Side region, Antalya-Turkey with regard to land use planning. Land Use Policy. Volume 44, Pages 90-100

Bishop, K. and Phillips, A. (2012).Countryside Planning: New Approaches to Management and Conservation. Routledge

Brabyn, L. (2005). Solutions for characterising natural landscapes in New Zealand using geographical information systems, Journal of Environmental Management, 76, 23-34.

Brabyn, L. (2009). Classifying landscape character, Landscape Research, 34(3), 299- 321.

Countryside Agency (2005). Report: A character assessment of Oxford in its landscape setting. Countryside Agency Publications, Wetherby. Countryside Agency and Scottish Natural Heritage.

Countryside Agency. (1999). Countryside Character Volume 8: South West, The Countryside Agency.

Countryside Council for Wales. (2001). Guide to Best Practice in Seascape Assessment. University College Dublin: Maritime Ireland/Wales Interreg, Report No. 5.

DETR, D. o. E., Transport and Regions, \& CABE, C. f. A. a. t. B. E. (2000). By Design: Urban Design in the Planning System. Great Britain: Crown.

European Landscape Convention. (2000). The European Landscape Convention, European Treaty, Series №. 176.

European Landscape Convention. (2007). Report: The European Landscape Convention Framework of Implementation in England.

Fairclough, G., Sarlöv Herlin, I. \& Swanwick, C. (Eds.). (2018). Landscape character: Experience from Britain. Handbook of landscape character assessment, Routledge (2018), pp. 21-36.

Laws of Malaysia: National Land Code 1965, Act No 56 of 1965 incorporating all amendments up to 31 August 2002.

Laws of Malaysia: Town and Country Planning Act 1976, Act No 172 of 1976 incorporating all amendments up to 1993.

Martín, B., Ortega, E., Rosa, I. \& Arce, M. (2016). Landscape character assessment with GIS using map-based indicators and photographs in the relationship between landscape and roads. Journal of Environmental Management. Volume 180, Pages 324-334.

Matloob, F. A. et al. (2014). Sustaining Campuses Through Physical Character- The Role Of Landscape / Procedia - Social and Behavioral Sciences 140 (2014) 282290.

NLP. (2011). National Landscape Policy. Kuala Lumpur: National Landscape Department, Ministry of Housing and Local Government.

Selman, P. (2000). Landscape sustainability at the national and regional scales. In: Benson, J.F., Roe, M.H. (Eds.), Landscape and Sustainability. London: Spon Press.

Swanwick, C. (2002). Landscape Character Assessment. Guidance for England and Scotland, Countryside Agency and Scottish Natural Heritage publication.

Swanwick, C. (2004). The assessment of countryside and landscape character in England: an overview. In: Bishop, K., Phillips, A. (Eds.), Countryside Planning.

Teh, M.Z., Pugi, N.A. \& Rahman, N.A. (2017). Visual Landscape Assessment for Development Landscape Structure: Case study at Taiping, Perak, E-BPJ, 2(5), March 2017 (p.231-238).

Trop, T. (2017). From knowledge to action: Bridging the gaps toward effective incorporation of Landscape Character Assessment approach in land-use planning and management in Israel. Land Use Policy. Volume 61, Pages 220-230.

Zakariya, K., Ibrahim, P. H. \& Abdul Wahab, N. A. (2019). Conceptual framework of rural landscape character assessment to guide tourism development in rural areas. Journal of Construction in Developing Countries, 24(1): 85-99. 